\title{
Aluminium in human brain tissue: how much is too much?
}

\author{
Christopher Exley $^{1} \cdot$ Matthew J. Mold $^{1}$
}

Received: 20 June 2019 / Accepted: 10 August 2019 / Published online: 29 August 2019

(c) The Author(s) 2019

\begin{abstract}
A burgeoning body of research confirms and affirms the presence of aluminium in human brain tissue. Recently, the first data on aluminium content of brain tissue from donors with diagnoses of familial Alzheimer's disease, autism spectrum disorder, multiple sclerosis and epilepsy have been published. Quantitative data are supported by aluminium-specific fluorescence microscopy identifying the locations of aluminium in human brain tissue. The challenge in the future will be to confirm or refute the role played by brain aluminium intoxication in human neurodegenerative disease.
\end{abstract}

Keywords Aluminium in brain tissue $\cdot$ Alzheimer's disease $\cdot$ Autism $\cdot$ Multiple sclerosis $\cdot$ Epilepsy $\cdot$ Aluminium-specific fluorescence microscopy $\cdot$ Neurodegenerative disease

Human exposure to aluminium is burgeoning [1]. Living in the 'aluminium age' ensures that the myriad ways in which we are exposed to aluminium today will be even more numerous tomorrow. Aluminium in human brain tissue is the inevitable consequence of this burgeoning exposure [2]. However, what are the consequences of aluminium in human brain tissue? We know that aluminium does not benefit the human brain and in 'excessive amounts' it is neurotoxic. The latter label of 'neurotoxicity' is widely accepted for humans only because of the experience of relatively rare occurrences of iatrogenic disease [3] and especially dialysis dementia [4]. While aluminium in brain tissue is inevitable when is it also toxic? How can we define toxicity thresholds and when does neurotoxicity achieve a phenotype in affected individuals. How much aluminium in brain tissue is too much?

We reviewed aluminium in human brain tissue almost 10 years ago [2] and in the period since, out with research in our group, there have not been any new quantitative data published on this subject. In 2012, we published the results of our 60 human brain study, an undertaking designed to provide robust and unequivocal data on the aluminium content of human brain tissue [5]. The research applied the most rigorous quality assurance methods possible including the measurement of 174 method blanks. We defined a method

Christopher Exley

c.exley@keele.ac.uk

1 The Birchall Centre, Lennard-Jones Laboratories, Keele University, Staffordshire ST5 5BG, UK blank as an estimate of sample contamination from all experimental procedures beginning with taking tissue samples at the brain bank through to analyses of brain digests by transversely heated graphite furnace atomic absorption spectrometry (TH GFAAS). The only difference with sample treatments being that method blanks did not include brain (any) tissues. The median amount of aluminium present as a contaminant was $22 \mathrm{ng} /$ reaction vessel (used for microwave-assisted digestion) and since the method blank data were not normally distributed, a log transformation was used to determine a contaminant level of $54 \mathrm{ng} / \mathrm{reac}-$ tion vessel (mean $+1.654 \mathrm{SD})$. This value is, thereafter, subtracted from all tissue digests carried out using identical experimental procedures. The final data obtained for 60 human brains were revealing in a number of ways. In the first instance, the median aluminium content for all 713 tissue samples was $1.02 \mu \mathrm{g} / \mathrm{g}$ dry wt., an aluminium content in human brain tissue that might be thought of as inevitable (in donors aged $70-103$ years) if not normal. However, scrutiny of data showed that in 41 of the 60 donors, the aluminium content of at least one tissue was above $3.00 \mu \mathrm{g} / \mathrm{g}$ dry wt., an aluminium content thereafter defined as pathologically significant [6]. While the brain bank that provided these tissues refused (retrospectively) to reveal the disease state of the individual donors it is a matter of published record that for this particular brain bank approximately $50 \%$ of donors had a diagnosis of dementia at death [7]. As such, the 60 human brain data set for aluminium constituted about 30 
donors with a diagnosis of Alzheimer's disease and 30 aged controls.

The nature of the aluminium data for the 60 human brains, range $0.01-33.00 \mu \mathrm{g} / \mathrm{g}$ dry wt., confirmed that which was already suspected, the focal as opposed to homogenous distribution of aluminium in human brain tissue [8]. It also questioned the value of brain tissue data based solely upon averages. Mean or median values would be informative where tissues were heavily overloaded with aluminium, but generally these statistics are more likely to hide important data on focal accumulations of aluminium. For example, not revealing areas of the brain where the aluminium content is sufficiently high to bring about, at the very least, focal neuropathology. We published the aluminium content of each of the three replicates of each tissue and eschewed the calculation of averages. We have continued the practice of publishing data for all replicates in all subsequent studies on aluminium in human brain tissue.

It is a rare privilege to work with human brain tissue, and weights of tissues available through brain banks are usually limited to less than $1 \mathrm{~g}$. However, on some occasions, an opportunity arises to analyse larger weights of tissue and we had such an opportunity for a case of Alzheimer's disease linked to occupational exposure to aluminium [9]. We were provided with approximately $20 \mathrm{~g}$ frozen weight of the frontal lobe and this was divided into approximately 50 separate samples. Our 60-brain study had identified $0.3-0.5 \mathrm{~g}$ as the optimal range for fresh weight of brain tissue. Wet weights below $0.3 \mathrm{~g}$ could result in dry weights where the influence of contaminating aluminium might be disproportionately high, whereas wet weights above $0.5 \mathrm{~g}$ were prone to incomplete digestion in the microwave. The concentration of aluminium (mean and SD) in the frontal lobe of brain tissue from this occupationally exposed individual was 2.98 (2.73) $\mu \mathrm{g} / \mathrm{g}$ dry wt. for 46 replicates. That $35 \%$ of the replicates had a concentration of aluminium above $3.00 \mu \mathrm{g} / \mathrm{g}$ dry wt. confirmed a possible role for aluminium in this individual's early-onset Alzheimer's disease. Once again, as was the case for brain tissues in the 60-brain study, the range of concentrations was wide from the limit of detection, $0.01-12.97 \mu \mathrm{g} / \mathrm{g}$ dry wt. and demonstrated the focal distribution of aluminium in human brain tissue.

Our subsequent studies have measured the aluminium content of brain tissue from donors who died with a diagnosis of familial Alzheimer's disease (fAD) [10], autism spectrum disorder (ASD) [11], multiple sclerosis (MS) [12] and epilepsy [13]. In fAD the concentration of aluminium ranged from 0.01 to $35.65 \mu \mathrm{g} / \mathrm{g}$ dry wt. with 11 out of 12 donor brains having at least one tissue where the aluminium content is considered as pathologically significant $(\geq 3.00 \mu \mathrm{g} / \mathrm{g}$ dry wt.). For ASD the concentration of aluminium ranged from 0.01 to $22.11 \mu \mathrm{g} / \mathrm{g}$ dry wt. with five out of five donor brains having at least one tissue where the aluminium content was considered as pathologically significant $(\geq 3.00 \mu \mathrm{g} / \mathrm{g}$ dry wt.). In MS donor tissue, aluminium concentrations ranged from 0.01 to $>50 \mu \mathrm{g} / \mathrm{g}$ dry wt. and all 14 donors had at least one tissue where the aluminium concentration was considered pathologically significant ( $\geq 3.00 \mu \mathrm{g} / \mathrm{g}$ dry wt.). Peer review of these published studies has consistently asked how brain aluminium data compare with control donor brains. In addressing this important criticism, a pertinent question is what constitutes control tissue in brain aluminium research. For example, is brain tissue from a donor who has not died from a particular disease, e.g. MS, suitable control tissue for that condition? It should be recognised that aluminium is a toxin and its presence in brain tissue is only inimical. All biologically reactive aluminium will be disruptive and, at the very least, will require energy use in compensating its presence. At some point, compensating a toxic threshold of aluminium will manifest as neurodegeneration identifiable as such by an experienced pathologist. Brain banks are not replete with healthy brains. The majority of brains are from aged donors with underlying conditions. To understand the role of aluminium in neurodegenerative disease including $\mathrm{AD}$, ASD and MS, ageand gender-matched healthy control brains are required. If available, such brain tissues would help in understanding if high concentrations of aluminium contribute towards neurodegeneration, for example, high levels of aluminium with no coincident neurodegeneration would suggest otherwise. Similarly, data on healthy brain tissue would help to identify concentrations of aluminium that would not be expected to contribute towards neurodegeneration. We have worked with a major brain bank in the UK to identify donor brains in which there is little or no neurodegeneration. We have identified 21 brains, the majority from aged donors, and we are currently measuring their aluminium content to help to address the points raised above about what constitutes control brain tissue and what content of aluminium we might expect to find in brain tissue unaffected by overt neurodegenerative disease.

Quantitative measurements of brain aluminium are informative, but their interpretation with respect of neurotoxicity requires additional information. Previous research has suggested that the distribution of aluminium in brain tissue is focal, being, for example, associated with neuropathology [2]. The recent development of aluminium-specific fluorescence microscopy [14] has not only been helpful in confirming the presence of aluminium in human brain tissue, but it has also identified the location of aluminium (Fig. 1). Imaging of aluminium has put quantitative data in context, for example, while both fAD and ASD showed some of the highest aluminium content, imaging identified clear differences in the location of aluminium. While in $\mathrm{AAD}$ deposits of aluminium were primarily extracellular [10], in ASD aluminium was mainly intracellular and associated 
Fig. 1 Aluminium imaged in the human brain. Lumogallion staining ( $1 \mathrm{mM}$ in $50 \mathrm{mM}$ PIPES, pH 7.4, 45 min.) of $5 \mu \mathrm{m}$ brain tissue sections from donors diagnosed with (a-c) autism spectrum disorder (ASD), $\mathbf{d}$ cerebral amyloid angiopathy (CAA), e epilepsy and f familial Alzheimer's disease (fAD). Intracellular aluminium in astrocytes (a, white arrow), microglia $\mathbf{b}$ and in endothelial cells in the lumen of a blood vessel $\mathbf{c}$ in donors diagnosed with ASD in a white matter of the hippocampus $\mathbf{b}$ the frontal cortex and $\mathbf{c}$ white matter of the parietal lobe. Intracellular aluminium in a neuronal cell in a donor diagnosed with CAA in grey matter of the hippocampus (d). Extracellular aluminium in the temporal cortex of a donor diagnosed with epilepsy (e) and (f) co-localised with a senile plaque in white matter of the frontal lobe of a donor diagnosed with fAD. Magnified inserts are denoted with asterisks and images were acquired using an Olympus U-MNIB3 fluorescence filter cube (excitation: 470-495 nm, dichromatic mirror: $505 \mathrm{~nm}$, longpass emission: $510 \mathrm{~nm}$ ). Magnification $\times 400$, scale bars: $50 \mu \mathrm{m}$
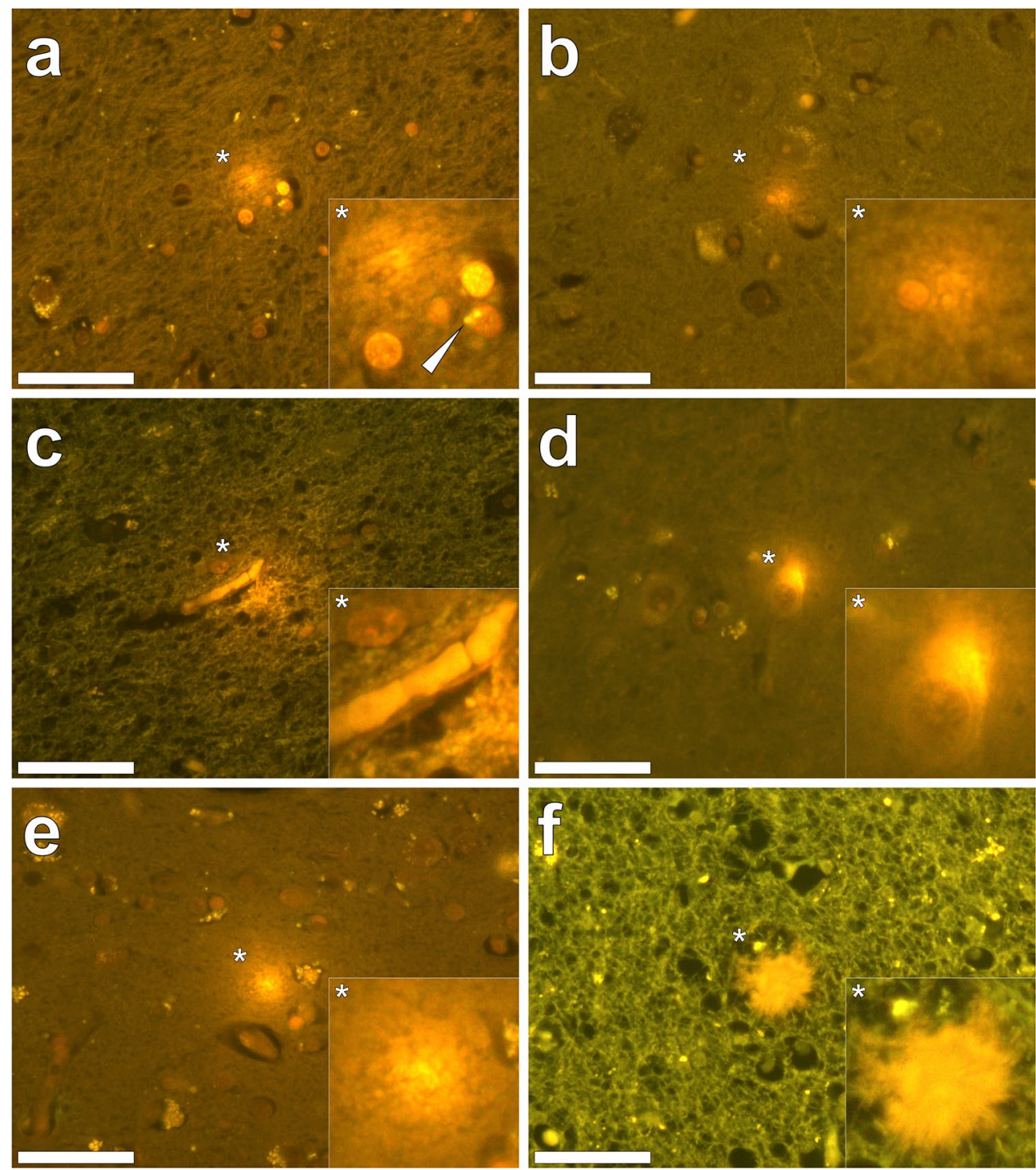

with non-neuronal cells such as microglia [11]. Imaging has also helped in identifying associations between aluminium and disease-specific neuropathology. For example, in fAD aluminium was co-localised with amyloid in senile plaques [10], whereas in cerebral amyloid angiopathy (CAA) deposits of aluminium were distinct from those of amyloid [15]. Similarly, while aluminium has been linked historically with neurofibrillary tangles in Alzheimer's disease [16], tau and aluminium were not co-located in late-onset adult epilepsy [13]. In MS, imaging has identified aluminium in both extra- and intracellular locations as well as associated with neuropathology including plaque-like structures and corpora amylacea [12].

Aluminium-specific fluorescence microscopy has confirmed that aluminium is not distributed homogenously in brain tissue and this informs us that even when an aluminium concentration of $1.00 \mu \mathrm{g} / \mathrm{g}$ dry wt. $(1 \mathrm{ppm})$ is determined for $0.500 \mathrm{~g}$ fresh weight of tissue, there will be regions within this sample of tissue where the concentration of aluminium is significantly higher than $1 \mathrm{ppm}$. These total concentrations of aluminium will be sources of biologically reactive aluminium with the potential for toxicity and even cytotoxicity [6]. Local toxicity may result in cellular and neuronal dysfunction and evoke compensatory mechanisms in affected cell populations. Where the concentration of aluminium in $0.500 \mathrm{~g}$ of fresh weight of tissue is in excess of $3.00 \mu \mathrm{g} / \mathrm{g}$ dry wt., there will be focal concentrations of aluminium in excess of $10 \mathrm{ppm}$ and the consequent local toxicity will be more overt and compensatory mechanisms less effective. Neurotoxicity is inevitable under such conditions and aluminium will either initiate a disease process or accelerate any disease processes that may be ongoing [17].

The presence of aluminium in brain tissue is an intoxication. It will inevitably exert toxicity at a local level. Future research is required to ascertain the significance of discrete aluminium-related neurotoxicity and how the additive effects 
of such neuropathologies may eventually contribute towards recognised global neurodegenerative disease characteristic of conditions such as AD, MS, epilepsy and ASD.

Open Access This article is distributed under the terms of the Creative Commons Attribution 4.0 International License (http://creativecommons.org/licenses/by/4.0/), which permits unrestricted use, distribution, and reproduction in any medium, provided you give appropriate credit to the original author(s) and the source, provide a link to the Creative Commons license, and indicate if changes were made.

\section{References}

1. Exley C (2013) Human exposure to aluminium. Environ Sci: Processes and Impacts 15:1807-1816

2. Exley C, House E (2011) Aluminium in the human brain. Monat Chem-Chem Mon 142:357-363

3. Reusche E, Pilz P, Oberascher G, Lindner B, Egensperger R, Gloeckner K, Trinka E, Iglseder B (2001) Subacute fatal aluminium encephalopathy after reconstructive otoneurosurgery: a case report. Human Pathol 32:1136-1140

4. Alfrey AC, Legendre GR, Kaehny WD (1976) Dialysis encephalopathy syndrome-possible aluminium intoxication. N Engl J Med 294:184-188

5. House E, Esiri M, Forster G, Ince PG, Exley C (2012) Aluminium, iron and copper in human brain tissues donated to the medical research council's cognitive function and ageing study. Metallomics 4:56-65

6. Exley C (2014) What is the risk of aluminium as a neurotoxin? Expert Rev Neurotherapeutics 14:589-591

7. Savva GM, Wharton SB, Ince PG, Forster G, Matthews FE, Brayne C (2009) Age, neuropathology and dementia. New Engl J Med 360:2302-2309
8. Solomon B, Koppel R, Jossiphov J (2001) Immunostaining of calmodulin and aluminium in Alzheimer-disease affected brain. Brain Res Bull 55:253-256

9. Exley C, Vickers T (2014) Elevated brain aluminium and early onset Alzheimer's disease in an individual occupationally exposed to aluminium: a case report. J Med Case Rep 8:41

10. Mirza A, King A, Troakes C, Exley C (2017) Aluminium in brain tissue in familial Alzheimer's disease. J Trace Elem Med Biol 40:30-36

11. Mold M, Umar D, King A, Exley C (2018) Aluminium in brain tissue in autism. J Trace Elem Med Biol 46:76-82

12. Mold M, Chmielecka A, Rodriguez MRR, Thom F, Linhart C, King A, Exley C (2018) Aluminium in brain tissue in multiple sclerosis. Int J Environ Res Public Health 15:1777

13. Mold M, Cottle J, Exley C (2019) Aluminium in brain tissue in epilepsy: a case report from Camelford. Int J Environ Res Public Health 16:2129

14. Mirza A, King A, Troakes C, Exley C (2016) The identification of aluminium in human brain tissue using lumogallion and fluorescence microscopy. J Alzh Dis 54:1333-1338

15. Mold M, Cottle J, King A, Exley C (2019) Intracellular aluminium in inflammatory and glial cells in cerebral amyloid angiopathy: a Case Report. Int J Environ Res Public Health 16:1459

16. Good PF, Perl DP, Bierer LM, Schmeidler J (1992) Selective accumulation of aluminium and iron in the neurofibrillary tangles of Alzheimer's disease: a laser microprobe (LAMMA) study. Ann Neurol 31:286-292

17. Exley C (2017) Aluminium should now be considered a primary aetiological factor in Alzheimer's disease. J Alzh Dis Rep 1:23-25

Publisher's Note Springer Nature remains neutral with regard to jurisdictional claims in published maps and institutional affiliations. 